\section{Liquid-liquid equilibria of the phosphoric acid, ester and water ternary system}

The Mining-Geology-Petroleum Engineering Bulletin UDC: $54.06 ; 54.08 ; 502,504,542.2 ; 542.6 ; 543$; $543.3 ; 544 ; 544.3 ; 550.4 ; 662.6$

DOI: 10.17794/rgn.2020.2.8

Original scientific paper

\author{
Vinod Jena ${ }^{1}$, Sanjay Ghosh ${ }^{1}$, Sapana Gupta ${ }^{2}$, Piyush Thakur' ${ }^{3}$, Noorjahan Ansari ${ }^{3}$, Natalija Matić ${ }^{4}$ \\ ${ }^{1}$ Department of Chemistry, Government Nagarjuna Post Graduate College of Science, Raipur, India \\ ${ }^{2}$ Department of Veterinary Services, Raipur, India \\ ${ }^{3}$ MATS University Raipur, Raipur, India \\ ${ }^{4}$ Department of Development, Hrvatske Vode [Croatian Waters], Zagreb, Croatia
}

\begin{abstract}
This paper presents an experimental methodology used for the determination of liquid-liquid equilibrium (LLE) data of the ternary system (phosphoric acid, ester and water). This experimental methodology represents the determination of phosphoric acid linked with different aquatic systems. In this study, an ester was selected as an organic solvent for the recovery of phosphoric acid from waste water. The binodal curve and the tie lines have been prominent. The ternary system (water + phosphoric acid + ester) was studied at three temperatures i.e. 25,35 and $45{ }^{\circ} \mathrm{C}(298,313$ and $323 \mathrm{~K})$. The results indicate that the extraction of phosphoric acid by a solvent is possible in aquatic systems. The results are discussed.
\end{abstract}

Keywords:

liquid-liquid equilibrium (LLE); ternary system; phosphoric acid; aquatic systems

\section{Introduction}

The quality of the aquatic system is dependent on the hydrogeochemical processes and reactions, the chemical and physical properties of surrounding rocks in the recharge area, the quantitative and qualitative properties of through-flowing water bodies and the products of human activity. Phosphoric acid plays a significant role and has applications in various industries of petrochemical operations, pharmaceutical productions, food industry, detergents, insecticides, and agricultural fertilizers (Parameswaran and Paluri, 1968; McCullough and Frederick, 1976; Ghanadzadeh Gilani et al., 2013; Bahrpaima, 2017; Shekarsaraee, 2017). Liquid-liquid extraction (LLE) is a technique used in the process industry due to its simplicity, rapid method development, and reasonable selectivity (Kumar et al., 2011; Hamdi and Hannachi, 2012; Bahrpaima, 2017). LLE is based on the differences in solubility and equilibrium distribution of these components between the two produced immiscible or partially miscible phases. In other words, it depends on the mass transfer of the component to be extracted from the carrier to the solvent. In order to have an effective extraction, the extract component should more preferably dissolve in the solvent.

Liquid-liquid extraction is an important traditional extraction (separation) method based on the varied solu-

Corresponding author: Natalija Matić

nmatic@voda.hr bility of chemicals in two different liquid solvents. This method is used in research and chemical analysis and is less commonly used for environmental analysis due to its large solvent usage and low target recoveries. As a commercial process, it is frequently used in the chemical and mining industries and in the downstream recovery of fermentation products (Dhouib-Sahnoun et al., 2002; Ghanadzadeh, et al., 2012; Bahrpaima et al., 2014; Medunić et al., 2018).

High levels of phosphorus $(\mathrm{P})$ can cause pollution and significant negative impacts on aquatic systems, food security, human health (Ngatia et al., 2019). The pollution of water bodies with $\mathrm{P}$ is often a consequence of human activity. Due to a combination of land management practices, land vulnerability and climatic factors, losses of $\mathrm{P}$ from agricultural land is a key contributor to the pollution of aquatic systems (Zhiguo et al., 2020). Urban and point sources also contribute to the pollution of water bodies with P. Industry and households are often the most important sources. Phosphorus substances in water bodies cause damage through eutrophication. Phosphates persist for long periods of time in aquatic environments and are recycled back into the environment when plants decompose (Bai et al., 2019). Phosphoric acid has adversely affected the aquatic life in waters of low alkalinity because it can be transported as dissolved in water. Control of $\mathrm{P}$ discharge is needed to reduce pollution levels in water bodies. The policy needs to support and evaluate sustainability. Numerous European 
Directives and Regulations control phosphates in water sources (Kirbaslar et al., 2006; Ghanadzadeh et al., 2019).

Phosphorus concentrations in natural waters are often near or below detection in pristine waters (about 0.001 to $0.01 \mathrm{ppm}$ ). The applied dose of $\mathrm{P}$ is initially around 1 $\mathrm{ppm}$, gradually decreasing to around $0.7 \mathrm{ppm}$, the treatment of phosphorous takes effect and the system becomes optimized. For comparison, the given values of phosphate concentrations and their environmental eligibility level are as follows: $0.01-0.03 \mathrm{ppm}-$ the level in uncontaminated lakes; $0.025-0.1 \mathrm{ppm}-$ the level at which plant growth is stimulated; $0.1 \mathrm{ppm}$ - the maximum acceptable level to avoid accelerated eutrophication and $>0.1 \mathrm{ppm}$ - accelerated growth and consequential problems (Blankestein, 2019).

Three tap water, three waste water and two pond water samples were investigated in the Talab area of Raipur City. Raipur is the capital city of the Indian state of Chhattisgarh. Chhattisgarh heritage is famous for its ponds. Ponds in the area of Raipur are affected by pollutants, and most of the pollutants in ponds are the product of different industrial activities. Raipur is located near the centre of a large plain. The Mahanadi River flows to the east of the City of Raipur. The Maikal Hills rise on the north-west of Raipur; on the north, the land rises and merges with the Chota Nagpur Plateau, which extends north-east across Jharkhand state. On the south of Raipur lies the Deccan Plateau. Raipur has a tropical wet and dry climate, and the highest temperature goes up to 43 ${ }^{\circ} \mathrm{C}$. Average rainfall is about $1300 \mathrm{~mm}$. The crystalline rocks (granite, granite gneiss, phyllite, and schist) achaean to recent age occupy major parts of the district. Also, limestone, shale, dolomite and sandstone belong to the Chhattisgarh Supergroup of Proterozoic age. There is an alluvium blanket along the major rivers and ponds. The major soil types are red gravelly/sandy (Alfisols), shallow black (Inceptisols), red and yellow, and lateritic (Ultisols) (Sahoo, 2013). The observed terrain was a subject of extensive aquatic investigations with a LLE ternary system for the first time during 2019 and investigations have shown that a ternary system (water + phosphoric acid + ester) is very useful for environmental analysis.

In this paper, the importance of one particular process is examined. The novelty of this research is based on the ternary system (water + phosphoric acid + ester) which is important for investigations of aquatic systems.

\section{Materials and methods}

Ternary phase behaviour of such systems at a constant temperature and pressure is conveniently represented on an equilateral diagram, where its corners indicate the pure components, binary compositions are along the edges and ternary mixtures are located inside the triangle. The binodal curve results are determined by the cloud point titration method (Mohsen-Nia et al., 2009). According to this method, a binary mixture of known composition was titrated with the third component in each mixture using non-sealed glass vessels. The transition point is taken as the appearance/disappearance of turbidity in the sample and it is defined as a cloud point. The mixture temperature is regulated by a thermostatic thermometer with an accuracy of $\pm 0.2 \mathrm{~K}$. Every point on the binodal curve also has another corresponding point on the binodal curve, as these two points represent the phase equilibrium. The lines between these two equilibrium points are called tie lines. The tie lines are usually not parallel, and their slopes can increase and decrease drastically. The biphasic mixture with known compositions was placed in the extraction cell and was rigorously agitated by a magnetic stirrer for $4 \mathrm{~h}$, and then left to settle for a minimum of $4 \mathrm{~h}$ for phase separation. After separation, the samples of both phases were transparent and were carefully weighed and analysed to determine their compositions. Then, the concentrations of the acid in both phases were obtained by potentiometric $\mathrm{NaOH}$ titration (Smirnov et al., 2019).

Solutions required for the ternary mixtures are phosphoric acid $\left(\mathrm{H}_{3} \mathrm{PO}_{4}\right)$, an ester (methyl acetate) and distilled water. Solution preparation is as follows: ten millilitres of homogeneous single-phase solutions of phosphoric acid and distilled water is prepared by the serial dilution law using a small, clean and dry flask. The preparation of all required solutions by serial dilutions with their percentage is given below in the tables (see Table 1 and Table 2).

Determination of percentage of phosphoric acid, distilled water and ester (methyl acetate):

\section{Calculation based on volume}

$$
\begin{gathered}
\% \text { of phosphoric acid }=\frac{100 x V_{1}}{V_{1}+V_{2}+V_{3}} \\
\% \text { of water }=\frac{100 x V_{2}}{V_{1}+V_{2}+V_{3}} \\
\% \text { of ester (methyl acetate })= \\
=100-(\% \text { of phosphoric acid }+\% \text { of water })=\frac{100 x V_{3}}{V_{1}+V_{2}+V_{3}}
\end{gathered}
$$

Where:

$$
\begin{aligned}
& V_{1}-\text { volume of phosphoric acid }(\mathrm{ml}) ; \\
& V_{2}-\text { volume of water }(\mathrm{ml}), \\
& V_{3}-\text { volume of ester (methyl acetate) }(\mathrm{ml}) . \\
& \text { Calculation based on mass }
\end{aligned}
$$

\section{Calculation based on mass}

$$
\begin{aligned}
& W_{1}=V_{1} \sigma_{1} \\
& W_{2}=V_{2} \sigma_{2} \\
& W_{3}=V_{3} \sigma_{3}
\end{aligned}
$$

Where: 
$\sigma_{1}$ - density of phosphoric acid $\left(1.885 \mathrm{~g} / \mathrm{cm}^{3}\right)$,

$\sigma_{2}$ - density of water $\left(1 \mathrm{~g} / \mathrm{cm}^{3}\right)$,

$\sigma_{3}$ - density of ester (methyl acetate) $\left(0.932 \mathrm{~g} / \mathrm{cm}^{3}\right)$

$$
\begin{gathered}
\% \text { of phosphoric acid }=\frac{100 x W_{1}}{W_{1}+W_{2}+W_{3}} \\
\% \text { of water }=\frac{100 x W_{2}}{W_{1}+W_{2}+W_{3}} \\
\% \text { of ester (methyl acetate) }=\frac{100 x W_{3}}{W_{1}+W_{2}+W_{3}}
\end{gathered}
$$

\section{Result and discussion}

In this paper, the importance of LLE is examined. The work brings together new information in this area of re- search of LLE and in the determination of phosphoric acid in different water sources. The solubility curves were investigated via the cloud point method in an equilibrium glass cell. For this purpose, binary mixtures with specified composition were introduced into a glass cell and the cell temperature was controlled by a water bath with an accuracy of $\pm 0.2 \mathrm{~K}$. The third part of the ternary mixture was added to the binary mixture and the endpoint was determined by changing the solution transparency from a non-homogenous solution to a heterogeneous one. The binodal curve data of the investigated system is listed below (see Table 1 and Table 2).

In recent years, significant investigations of LLE measurements and the extraction of phosphoric acid from aqueous solutions have been carried out, while many solvents have mainly been tested in order to understand and provide further information for the accu-
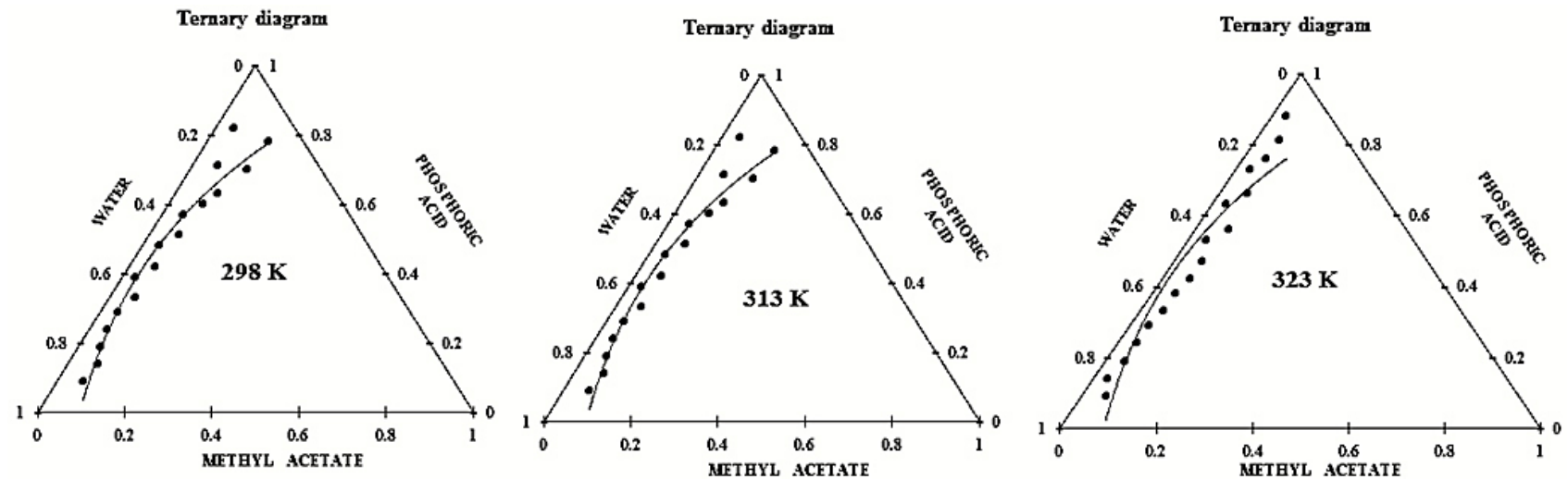

\begin{tabular}{|c|c|c|c|c|c|c|c|c|c|}
\hline \multirow{2}{*}{$\begin{array}{l}\text { Serial } \\
\text { number }\end{array}$} & \multicolumn{3}{|c|}{$25^{\circ} \mathrm{C}(298 \mathrm{~K})$} & \multicolumn{3}{|c|}{$35^{\circ} \mathrm{C}(313 \mathrm{~K})$} & \multicolumn{3}{|c|}{$45^{\circ} \mathrm{C}(323 \mathrm{~K})$} \\
\hline & $\begin{array}{c}\text { Ester } \\
\text { (in \%) }\end{array}$ & $\begin{array}{l}\text { phosphoric } \\
\text { acid (in \%) }\end{array}$ & $\begin{array}{l}\text { water } \\
\text { (in \%) }\end{array}$ & $\begin{array}{l}\text { Ester } \\
\text { (in \%) }\end{array}$ & $\begin{array}{l}\text { phosphoric } \\
\text { acid (in \%) }\end{array}$ & $\begin{array}{l}\text { water } \\
\text { (in \%) }\end{array}$ & $\begin{array}{l}\text { Ester } \\
\text { (in \%) }\end{array}$ & $\begin{array}{l}\text { phosphoric } \\
\text { acid (in \%) }\end{array}$ & $\begin{array}{l}\text { water } \\
\text { (in \%) }\end{array}$ \\
\hline 1 & 0.06 & 0.09 & 0.85 & 0.06 & 0.09 & 0.85 & 0.05 & 0.09 & 0.86 \\
\hline 2 & 0.04 & 0.14 & 0.82 & 0.07 & 0.14 & 0.79 & 0.03 & 0.14 & 0.83 \\
\hline 3 & 0.08 & 0.18 & 0.74 & 0.05 & 0.19 & 0.76 & 0.04 & 0.19 & 0.77 \\
\hline 4 & 0.04 & 0.24 & 0.72 & 0.04 & 0.24 & 0.72 & 0.04 & 0.24 & 0.72 \\
\hline 5 & 0.06 & 0.28 & 0.66 & 0.04 & 0.29 & 0.67 & 0.04 & 0.29 & 0.67 \\
\hline 6 & 0.06 & 0.33 & 0.61 & 0.06 & 0.33 & 0.61 & 0.05 & 0.33 & 0.62 \\
\hline 7 & 0.04 & 0.38 & 0.58 & 0.03 & 0.39 & 0.58 & 0.05 & 0.38 & 0.57 \\
\hline 8 & 0.07 & 0.42 & 0.51 & 0.06 & 0.42 & 0.52 & 0.06 & 0.42 & 0.52 \\
\hline 9 & 0.06 & 0.47 & 0.47 & 0.04 & 0.48 & 0.48 & 0.06 & 0.47 & 0.47 \\
\hline 10 & 0.09 & 0.50 & 0.41 & 0.07 & 0.51 & 0.42 & 0.04 & 0.53 & 0.43 \\
\hline 11 & 0.1 & 0.54 & 0.36 & 0.05 & 0.57 & 0.38 & 0.07 & 0.56 & 0.37 \\
\hline 12 & 0.06 & 0.61 & 0.33 & 0.08 & 0.6 & 0.32 & 0.03 & 0.63 & 0.34 \\
\hline 13 & 0.09 & 0.64 & 0.27 & 0.10 & 0.63 & 0.27 & 0.06 & 0.66 & 0.28 \\
\hline 14 & 0.04 & 0.72 & 0.24 & 0.06 & 0.71 & 0.23 & 0.03 & 0.73 & 0.24 \\
\hline 15 & 0.05 & 0.76 & 0.19 & 0.13 & 0.7 & 0.17 & 0.05 & 0.76 & 0.19 \\
\hline 16 & 0.07 & 0.82 & 0.11 & 0.04 & 0.82 & 0.14 & 0.05 & 0.81 & 0.14 \\
\hline 17 & 0.07 & 0.84 & 0.09 & 0.14 & 0.78 & 0.08 & 0.03 & 0.88 & 0.09 \\
\hline
\end{tabular}

Figure 1: Volume based ternary phase at $298 \mathrm{~K}, 313 \mathrm{~K}$ and $323 \mathrm{~K}$

Table 1: Volume-based ternary system composition 

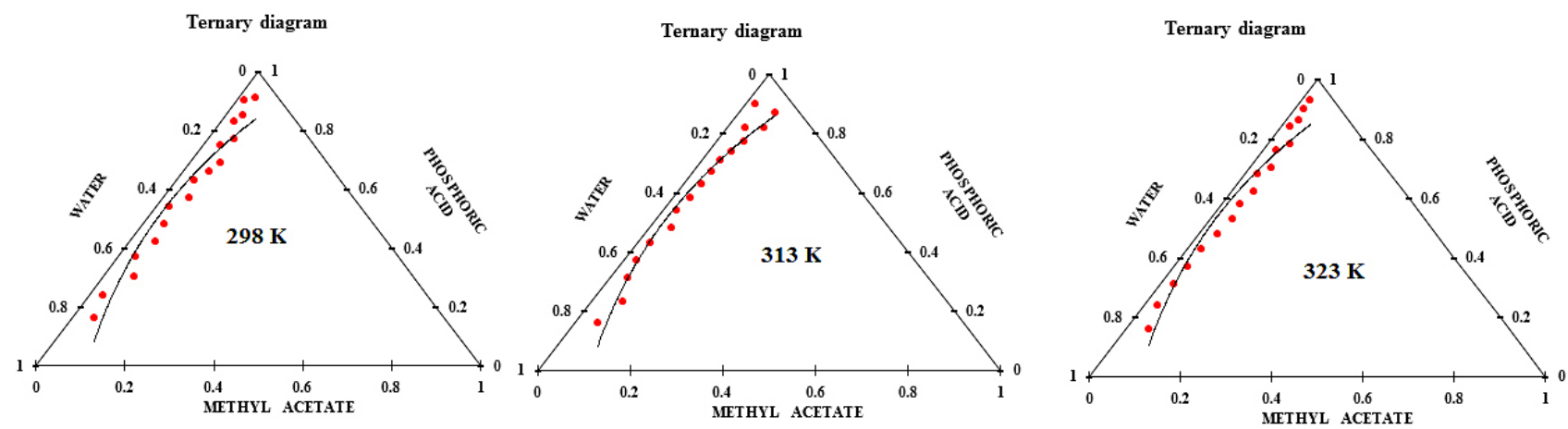

Figure 2: Mass based ternary phase at $298 \mathrm{~K}, 313 \mathrm{~K}$ and $323 \mathrm{~K}$

Table 2: Mass-based ternary system composition

\begin{tabular}{|c|c|c|c|c|c|c|c|c|c|}
\hline \multirow{2}{*}{$\begin{array}{l}\text { Serial } \\
\text { number }\end{array}$} & \multicolumn{3}{|c|}{$25^{\circ} \mathrm{C}(298 \mathrm{~K})$} & \multicolumn{3}{|c|}{$35^{\circ} \mathrm{C}(313 \mathrm{~K})$} & \multicolumn{3}{|c|}{$45^{\circ} \mathrm{C}(323 \mathrm{~K})$} \\
\hline & $\begin{array}{l}\text { Ester } \\
\text { (in \%) }\end{array}$ & $\begin{array}{l}\text { Phosphoric } \\
\text { acid (in \%) }\end{array}$ & $\begin{array}{l}\text { Water } \\
\text { (in \%) }\end{array}$ & $\begin{array}{l}\text { Ester } \\
\text { (in \%) }\end{array}$ & $\begin{array}{l}\text { Phosphoric } \\
\text { acid (in \%) }\end{array}$ & $\begin{array}{l}\text { Water } \\
\text { (in \%) }\end{array}$ & $\begin{array}{l}\text { Ester } \\
\text { (in \%) }\end{array}$ & $\begin{array}{l}\text { Phosphoric } \\
\text { acid (in \%) }\end{array}$ & $\begin{array}{l}\text { Water } \\
\text { (in \%) }\end{array}$ \\
\hline 1 & 0.05 & 0.16 & 0.79 & 0.05 & 0.16 & 0.79 & 0.05 & 0.16 & 0.79 \\
\hline 2 & 0.03 & 0.24 & 0.73 & 0.07 & 0.23 & 0.7 & 0.03 & 0.24 & 0.73 \\
\hline 3 & 0.07 & 0.3 & 0.63 & 0.04 & 0.31 & 0.65 & 0.03 & 0.31 & 0.66 \\
\hline 4 & 0.04 & 0.37 & 0.59 & 0.03 & 0.37 & 0.6 & 0.03 & 0.37 & 0.6 \\
\hline 5 & 0.06 & 0.42 & 0.52 & 0.03 & 0.43 & 0.54 & 0.03 & 0.43 & 0.54 \\
\hline 6 & 0.05 & 0.48 & 0.47 & 0.05 & 0.48 & 0.47 & 0.04 & 0.48 & 0.48 \\
\hline 7 & 0.03 & 0.54 & 0.43 & 0.03 & 0.54 & 0.43 & 0.05 & 0.53 & 0.42 \\
\hline 8 & 0.06 & 0.57 & 0.37 & 0.04 & 0.58 & 0.38 & 0.04 & 0.58 & 0.38 \\
\hline 9 & 0.04 & 0.63 & 0.33 & 0.04 & 0.63 & 0.33 & 0.05 & 0.62 & 0.33 \\
\hline 10 & 0.06 & 0.66 & 0.28 & 0.04 & 0.67 & 0.29 & 0.03 & 0.68 & 0.29 \\
\hline 11 & 0.07 & 0.69 & 0.24 & 0.04 & 0.71 & 0.25 & 0.05 & 0.7 & 0.25 \\
\hline 12 & 0.04 & 0.75 & 0.21 & 0.05 & 0.74 & 0.21 & 0.03 & 0.76 & 0.21 \\
\hline 13 & 0.06 & 0.77 & 0.17 & 0.06 & 0.77 & 0.17 & 0.05 & 0.78 & 0.17 \\
\hline 14 & 0.03 & 0.83 & 0.14 & 0.04 & 0.82 & 0.14 & 0.02 & 0.84 & 0.14 \\
\hline 15 & 0.04 & 0.85 & 0.11 & 0.08 & 0.82 & 0.1 & 0.03 & 0.86 & 0.11 \\
\hline 16 & 0.02 & 0.9 & 0.08 & 0.02 & 0.9 & 0.08 & 0.02 & 0.9 & 0.08 \\
\hline 17 & 0.04 & 0.91 & 0.05 & 0.08 & 0.87 & 0.05 & 0.02 & 0.93 & 0.05 \\
\hline
\end{tabular}

rate interpretation of phase equilibrium of the different multicomponent mixtures with phosphoric acid. A ternary phase diagram for a phosphoric acid, water and ester (methyl acetate) curve represents a possible equilibrium condition of phosphoric acid, water and ester (methyl acetate). The area above the curve represents one phase while the area below the curve represents a twophase system. A ternary phase diagram of liquid-liquid equilibrium of these three components at 25, 35 and 45 ${ }^{\circ} \mathrm{C}(298,313$ and $323 \mathrm{~K})$ on volume base is given below (see Table 1 and Figure 1).

To separate the homogeneous mixture of phosphoric acid and water through an ester at a temperature of i.e. $25{ }^{\circ} \mathrm{C}(298 \mathrm{~K})$, the amount of ester (methyl acetate) required is in the range of 0.15 to $0.53 \mathrm{ml}$. To separate the homogeneous mixture of phosphoric acid and water through an ester at a higher temperature i.e. $35^{\circ} \mathrm{C}(313$
$\mathrm{K}$ ), the amount of ester (methyl acetate) required is in the range of 0.105 to $0.53 \mathrm{ml}$ which is similar to the amount used at $25^{\circ} \mathrm{C}(298 \mathrm{~K})$. To separate the homogeneous mixture of phosphoric acid and water through an ester at an even higher temperature i.e. $45^{\circ} \mathrm{C}(323 \mathrm{~K})$, the amount of ester (methyl acetate) required is in the range of 0.09 to $0.47 \mathrm{ml}$ which is less than the amount used at $25^{\circ} \mathrm{C}(298 \mathrm{~K})$ and $35^{\circ} \mathrm{C}(313 \mathrm{~K})$. Hence, a comparison of all the three-phase diagrams based on volume at three different temperatures i.e. 25,35 and $45^{\circ} \mathrm{C}(298$, 313 and $323 \mathrm{~K}$ ), shows that the ternary phase diagram of $45^{\circ} \mathrm{C}(323 \mathrm{~K})$ is a better ternary diagram.

A ternary phase diagram of liquid-liquid equilibrium of these three components at 25,35 and $45^{\circ} \mathrm{C}(298,313$ and $323 \mathrm{~K}$ ) on mass base is given below (see Table 2 and Figure 2). To separate the homogeneous mixture of phosphoric acid and water through an ester at tempera- 
ture i.e. $25^{\circ} \mathrm{C}(298 \mathrm{~K})$, the amount of ester (methyl acetate) required is in the range of 0.13 to $0.49 \mathrm{ml}$.

The results indicate that the there is no variation of phosphoric acid determination in water using an ester at different temperatures. As the temperature varies, the phosphoric acid concentration remains constant. This indicates that phosphoric acid can be measured at a low temperature and is independent of temperature. To separate the homogeneous mixture of phosphoric acid and water through an ester at a temperature of $35^{\circ} \mathrm{C}(313 \mathrm{~K})$, the amount of ester (methyl acetate) required is in the range of 0.13 to $0.51 \mathrm{ml}$. To separate the homogeneous mixture of phosphoric acid and water through an ester at a temperature of $45^{\circ} \mathrm{C}(323 \mathrm{~K})$, the amount of ester (methyl acetate) required is in the range of 0.13 to $0.48 \mathrm{ml}$. By considering the importance of the extraction of phosphoric acid from aqueous mixtures, it is worthwhile to study the LLE of mixtures (see Figure 1 and Figure 2). The correlation factor is close to 1.0 and the linearity of the plots shows a degree of consistency and the quality of the obtained LLE values of the studies. This means that the two variables are almost perfectly correlated. If one grows, so does the other, and a change in one is a multiple of the change in the other. Correlation coefficients are used to measure the strength of the relationship between two variables. A correlation of almost 1.0 indicates an almost perfect positive correlation and its positive relationship.

As the temperature of a solution increases, it is easier for the molecules of the liquids to move between each other and it makes the solution more disordered. As seen, the temperature effect on the separation factors of the ternary system is small at the studied temperatures, probably because of the low mutual solubility of water and the solvent. This indicates that the extraction of phosphoric acid with ester as the solvent is possible. Also, the method is applicable when phosphorus concentrations are above $2 \mathrm{ppm}$ (so high-level values of $\mathrm{P}$ can be found in an aquatic system near a fertilizer industry in an agriculture area, pond water, wastewater, etc.). Three tap water samples, three waste water samples and two pond water samples were investigated at the location of the city of Raipur in India.

The results indicate that phosphoric acid, water and ester form a homogeneous phase. Extraction of phosphoric acid by the solvent ester is possible. The applicability of the method is presented by the results according to Table 3. at a temperature of $25^{\circ} \mathrm{C}(298 \mathrm{~K})$.

The results show that ester is a good solvent for extracting phosphoric acid from water at a temperature of $25^{\circ} \mathrm{C}(298 \mathrm{~K})$. Small amounts of phosphoric acid can be detected with an ester. In the waste water, the amount of phosphoric acid is higher than in the tap water or in the pond water. To determine the amount of phosphoric acid in waste water, a smaller amount of ester is required than for tap water. The amount of phosphoric acid in pond water is higher than in tap water and for determination of
Table 3: Composition of water samples studied at a temperature of $25^{\circ} \mathrm{C}(298 \mathrm{~K})$

\begin{tabular}{|l|c|c|}
\hline $\begin{array}{l}\text { Phosphoric acid } \\
\text { (in \%) }\end{array}$ & $\begin{array}{c}\text { Water } \\
\text { (in \%) }\end{array}$ & $\begin{array}{c}\text { Ester } \\
\text { (in \%) }\end{array}$ \\
\hline Tap water & \multicolumn{2}{|l|}{} \\
\hline 9 & $9.9 \%$ & $81.1 \%$ \\
\hline 14 & 11 & 75 \\
\hline 17.5 & 12.3 & 70.2 \\
\hline Waste water & 27 & 40.2 \\
\hline 32.8 & 32.8 & 30.3 \\
\hline 36.9 & 33.3 & 26.1 \\
\hline 40.6 & 21 & 51 \\
\hline Pond water & 26 & 44.4 \\
\hline 28 &
\end{tabular}

phosphoric acid, the pond water requires a lower amount of ester than is necessary for tap water. The amount of ester required to separate the phosphoric acid-water homogeneous phase is higher at higher temperatures according to the experimental data.

The correlation factor $\mathrm{R}^{2}$ values to unity $\left(\mathrm{R}^{2}=0.98\right)$ indicates the high degree of consistency of measured LLE data in this study. This method is used to study the $P$ concentration in pond water $(n=2)$, waste water $(n=$ 3 ) and tap water $(n=3)$. In all cases the value of $R^{2}$ is closeness to unity $\left(\mathrm{R}^{2}=0.98\right)$ which reveals accuracy of the experiments.

\section{Conclusion}

This paper brings new information in the area of research of liquid-liquid equilibrium (water + phosphoric acid + ester) and its application to aquatic systems. The liquid-liquid equilibrium thermodynamic properties of water + phosphoric acid + ester can be used in research on the nature of mixing behaviour of ternary systems for molecular models and industrial applications. Phosphoric acid, water and ester is a ternary system with one pair of miscible liquids (phosphoric acid and water) which form a homogeneous phase. The addition of a sufficient amount of ester to the phosphoric acid-water system would produce a heterogeneous phase in which two distinct layers appear. In the volume-based ternary phase diagram, a temperature of $45^{\circ} \mathrm{C}(323 \mathrm{~K})$ is observed to be better than the others, in regard to the amount of ester required to separate the phosphoric acid-water homogeneous phase. When the mass-based ternary phase diagram of the phosphoric acid-water-ester (methyl acetate) system is plotted at three different temperatures, a ternary phase diagram of temperature of $45^{\circ} \mathrm{C}(323 \mathrm{~K})$ is observed better than the others in regard to the amount of ester required to separate the phosphoric acid-water homogeneous phase. 


\section{Acknowledgment}

We would like to thank Department of Chemistry, Government Nagarjuna Post Graduate College of Science, Raipur, India for their support in laboratory work. We are very grateful for the help of Mr. Filip Vučić. The English language was edited by Ms. Tatjana Jauk, linguist and native speaker Mrs. Lisa Starčević and we thank them a lot for their kind help. We would like to thank the reviewers for their guidance and we would also like to thank the staff of the Journal.

\section{References}

Bahrpaima, K., Ebrahimi, M., Madani, H. and Shekarriz, S. (2014): Salting-out effect on the (liquid p liquid) equilibrium for the ternary systems (water $\mathrm{b}$ phosphoric acid $\mathrm{p}$ dichloromethane or 1,2-dichloroethane). Journal of Chemical Thermodynamics, 71, 118-125. DOI: $10.1016 /$ j. jct.2013.11.034.

Bahrpaima, K. (2017): Purification of Phosphoric Acid by Liquid-Liquid Equilibrium. In: Schorr, M. and Valdez, B. (eds.): Phosphoric Acid Industry - Problems and Solutions. - Intech Open, London, 7, 852. DOI: 10.5772/intechopen70031.

Bai, W., Dal, R., Pan, X., Zhu, Z., Wang, Y. and Gao, J. (2019): Liquid-liquid equilibria for azeotropic mixture of methyl tert-butyl ether and methanol with ionic liquids at different temperatures. Journal of Chemical Thermodynamics, 132, 76-82. https://doi.org/10.1016/j.jct.2018.12.029.

Blankesteijn, M. (2019): From measuring to removing to recovering phosphorus in water management in the Netherlands: Challenges for science-based innovation. Science of the Total Environment, 666, 801-811. https://doi. org/10.1016/j.scitotenv.2019.02.230.

Dhouib-Sahnoun, R., Feki, M. and Ayedi, H.F. (2002): Liquidliquid equilibria of the ternary system water $\mathrm{b}$ phosphoric acid p tributyl phosphate at $298.15 \mathrm{~K}$ and $323.15 \mathrm{~K}$. Journal of Chemical \& Engineering Data, 47, 861-866. https:// doi.org/10.1021/je010293r.

Ghanadzadeh, H., Ghanadzadeh, A., Shekarsaraee, S. and Uslu, H. (2012): Liquid phase equilibria of the system (water p phosphoric acid p 1-octanol) at T 1/4 (298.2, 308.2, and 318.2) K. Fluid Phase Equilibria, 316, 109-116. DOI: 10.1016/j.fluid.2011.12.016.

Ghanadzadeh Gilani, H., Ghanadzadeh Gilani, A. and Shekarsaraee, S. (2013): Experimental study of phase equilibria in aqueous mixtures of phosphoric acid with isoamyl acetate and methyl isoamyl ketone at $\mathrm{T} 1 / 4(298.2,308.2$, and 318.2) K. Fluid Phase Equilibria, 337, 32-38. https://doi. org/10.1016/j.fluid.2012.09.038.

Ghanadzadeh, G., Ahmadifar, A. and Taki, T. (2019): Experimental and modeling study of liquid phase equilibria for (water + phosphoric acid + sec-alcohols) systems. Journal of Chemical Thermodynamics 135, 305-315. https://doi. org/10.1016/j.jct.2019.04.005.

Hamdi, R. and Hannachi, A. (2012): Comparative simulation of the purification of wet phosphoric acid by tbp, mibk and a mixture (MIBK+TBP). Journal of Chemical Engineering \& Process Technology, 3, 2. DOI: 10.4172/2157-7048. 1000134.

Kurbaslar, S.I., Sahin, S. and Bilgin, M. (2006): (Liquid + liquid) equilibria of (water + propionic acid + alcohol) ternary systems. Journal of Chemical Thermodynamics, 38, 1503-1509. https://doi.org/10.1016/j.jct.2006.05.001.

Kumar, B.N., Radhika, S., Kantam, M.L. and Reddy, B.R. (2011): Solid-liquid extraction of terbium from phosphoric acid solutions using solvent-impregnated resin containing TOPS 99. Journal of Chemical Technology and Biotechnology, 86, 562-569. https://doi.org/10.1002/jctb. 2553.

McCullough, J.F. and Frederick, L.L. (1976): Purification of phosphoric acid with methanol and ammonia. Journal of Agricultural and Food Chemistry, 24, 180-187. https:// pubs.acs.org/doi/abs/10.1021/jf60203a050.

Medunić, G., Kuharić, Ž., Fiket, Ž., Bajramović, M., Singh, A.L., Krivohlavek, A., Kniewald, G. and Dujmović, L. (2018): Selenium and other potentially toxic elements in vegetables and tissues of three non-migratory birds exposed to soil, water, and aquatic sediment contaminated with seleniferous Raša coal. The Mining-Geology-Petroleum Engineering Bulletin, 2018, 53-62. DOI: 10.17794/ rgn.2018.3.6.

Mohsen-Nia, M., Jazi, B. and Amiri, H. (2009): Binodal curve measurementsfor(water+propionicacid+dichloromethane) ternary system by cloud point method, Journal of Chemical Thermodynamics, 41, 859-863. https://doi.org/10.1016/ j.jct.2009.02.004.

Ngatia, L, Johnny, M., Grace III Moriasi, D. and Taylor, R. (2019): Nitrogen and Phosphorus Eutrophication in Marine Ecosystems. In: Fouzia, H.B. (ed.): Monitoring of Marine Pollution, - IntechOpen, London, DOI: 10.5772/ intechopen.81869.

Parameswaran, A. and Paluri, B.R. (1968): Ternary liquid equilibria of the water-phosphoric acidisoamyl alcohol, cyclohexanol, or methyl isobutyl ketone systems at $35^{\circ} \mathrm{C}$. Journal of Chemical \& Engineering Data, 2, 194-196.

Sahoo, M. (2013): Ground water brochure of Raipur district, Chhattisgarh 2012-2013. Government of India ministy of water resources central ground water board. Raipur.

Shekarsaraee, S. (2017): Liquid-liquid equilibrium study for the system (water $\mathrm{p}$ phosphoric acid $\mathrm{p}$ propylene carbonate) at different temperatures. Journal of Chemical Thermodynamics, 104, 16-23. DOI: 10.1016/j.jct.2016.09.008.

Smirnov, A., Sadaeva, A., Podryadova, K. and Toikka, M. (2019): Quaternary liquid-liquid equilibrium, solubility and critical states: Acetic acid -n-butanol -n-butyl acetate - water at $318.15 \mathrm{~K}$ and atmospheric pressure, Fluid Phase Equilibria, 4931,102-108. https://doi.org/10.1016/j.fluid.2019.04.020.

Zhiguo, L., Runhua, Z., Chuang, L., Runqin, Z., Fang, C. and Yi, L. (2020): Phosphorus spatial distribution and pollution risk assessment in agricultural soil around the Danjiangkou reservoir, China. Science of the Total Environment, 699, 134-417. https://doi.org/10.1016/j.scitotenv.2019.134417. 


\section{SAŽETAK}

\section{Ravnoteža kapljevina-kapljevina u trodijelnome sustavu fosforne kiseline, estera i vode}

Rad prikazuje eksperimentalnu metodologiju koja se koristi za određivanje ravnoteže sustava kapljevina-kapljevina (fosforna kiselina, ester i voda). Ova eksperimentalna metodologija razvijena je za određivanje fosforne kiseline povezane s različitim vodenim sustavima. U ovome istraživanju ester je izabran kao organsko otapalo kako bi se utvrdila fosforna kiselina u otpadnim vodama. Istaknute su binodalna krivulja i vezne linije. Trodijelni sustav (voda + fosforna kiselina + ester) ispitan je na trima temperaturama, od 25,35 i $45^{\circ} \mathrm{C}(298,313$ i $323 \mathrm{~K})$. Rezultat upućuje na to da je odvajanje fosforne kiseline otapalom moguće pri istraživanju vodenih sustava.

\section{Ključne riječi:}

ravnoteža tekuće-tekuće, trodijelni sustav, fosforna kiselina, vodeni sustavi

\section{Authors contribution}

Vinod Jena (Ph.D.) and Sapana Gupta (Ph.D.) initialized the idea and participated in all work stages. Piyush Thakur (Ph.D.) and Noorjahan (MSc.) completed literature review, executed experimental tests and presentation of all results. Natalija Matic (Ph.D.) has research interest including hydrogeology, environmental pollution, water and wastewater management. She supervised data analysis and helped with defining the aim, problem, discussion and conclusion. Sanjay Ghosh (Ph.D.) completed experimental and kinetic part of the study. 